\title{
Sprawozdanie
}

\section{Konferencja nt.: Konstytucja RP w pierwszych dekadach XXI wieku wobec wyzwań politycznych, gospodarczych, technologicznych i spotecznych, Trybunal Konstytucyjny, Warszawa, 17 października 2012 r.}

W dniu 17 października 2012 r. w siedzibie Trybunału Konstytucyjnego odbyła się konferencja jubileuszowa z okazji piętnastej rocznicy wejścia w życie Konstytucji Rzeczypospolitej Polskiej. Inicjatorami konferencji byli prezesi Trybunału Konstytucyjnego - prof. Andrzej Rzepliński oraz prof. Stanisław Biernat. Zaproszenie do udziału w tym doniosłym wydarzeniu skierowano do młodych naukowców: doktorantów, doktorów i doktorów habilitowanych prawa, którzy w 1997 r. mieli nie więcej niż 18 lat. Adresatami zaproszenia były więc osoby, których całe dorosłe życie przebiegało wyłącznie pod rządami obowiązującej Konstytucji.

Do wystąpienia podczas Konferencji zgłosiło się czterdzieści siedem osób. Spośród nadesłanych projektów referatów komisja składająca się z sześciu sędziów Trybunału Konstytucyjnego wyłoniła dwudziestu prelegentów, którzy wygłosili swoje referaty podczas konferencji. Wybór referatów - jak podkreślił to prezes TK - dokonany został z uwzględnieniem m.in. adekwatności tematu do koncepcji konferencji, oryginalności ujęcia i różnorodności prezentowanych treści. Istotną determinantą dla komisji była również różnorodność „geograficzna” referentów. Wybrani zostali przedstawiciele z dziewięciu ośrodków akademickich z całego kraju.

$\mathrm{Na}$ konferencję przybyło wielu znamienitych gości. Uroczystość uświetnili swą obecnością m.in. prezydent Rzeczypospolitej Polskiej Bronisław Komorowski, marszałek Sejmu Ewa Kopacz, rzecznik praw obywatelskich pro- 
fesor Irena Lipowicz, sędziowie, prokuratorzy, a także przedstawiciele nauki prawa i korporacji prawniczych.

Uroczystego otwarcia obrad dokonał prezes Trybunału Konstytucyjnego - profesor Andrzej Rzepliński. W swym wystąpieniu skupił się przede wszystkim na wyjaśnieniu idei konferencji. Wskazał, że właśnie to pokolenie naukowców zaproszonych do udziału w konferencji będzie w przyszłości podejmować doniosłe decyzje w zakresie wykładni i stosowania przepisów ustawy zasadniczej. $\mathrm{Z}$ tego względu tak cenne są wszelkie inicjatywy aktywizujące i mobilizujące młodych badaczy. Jak stwierdził profesor Rzepliński: „Kiedy zastanawialiśmy się, jak uczcić 15 lat obowiązywania Konstytucji, ustawy zasadniczej, która reguluje życie Państwa Polskiego, gospodarki, społeczeństwa, a przede wszystkim ma służyć ochronie praw podstawowych, wpadliśmy na pomysł - razem z Wiceprezesem profesorem Stanisławem Biernatem - zorganizowania konferencji, podczas której o ustawie zasadniczej wypowiedzieliby się młodzi prawnicy. Myślę, że to rzeczywiście pozwoli nam, tym, którzy brali udział w tworzeniu tej Konstytucji, którzy o niej pisali przez ostatnie 15 lat i tym, którzy ją stosują, popatrzeć na nią z perspektywy tych, którzy za 15-20 lat będą podejmować ważne decyzje, nie tylko na uniwersytetach czy w sądzie konstytucyjnym, ale i w urzędach, decyzje oparte na Konstytucji”.

Po otwarciu obrad przez prezesa Trybunału Konstytucyjnego głos zabrała pani marszałek Sejmu Ewa Kopacz. Z pełną aprobatą odniosła się do koncepcji konferencji zaproponowanej przez prezesa TK. Podkreśliła przy tym, że „Państwo prawa istnieje wtedy, kiedy organizacja i działanie władzy publicznej oparte są na prawie, wtedy, kiedy prawem związane jest społeczeństwo i władza i gdy prawo stoi ponad władzą". W tej kwestii pani marszałek dostrzegła szczególną rolę prawników, odpowiedzialnych za czuwanie, aby instytucje państwowe działały zgodnie z prawem i na jego podstawie. Stwierdziła przy tym, że „demokratyczne państwo prawa to państwo codziennej uczciwości i uczynności w stosunku do obywatela, to zrozumiałe i akceptowane prawo, to urzędnik traktujący swój tytuł i stanowisko jako powołanie do służby publicznej, a nie do sprawowania władzy”. Kończąc swoje wystąpienie, pani marszałek złożyła wszystkim obecnym na sali obrad życzenia, aby Konstytucja RP była stosowana w taki sposób, jak ujęto to w preambule, tj. z poszanowaniem przyrodzonej godności człowieka, jego prawa do wol- 
ności i obowiązku solidarności z innymi, co stanowi niewzruszoną podstawę Rzeczypospolitej Polskiej.

Jako następny zabrał głos profesor Andrzej Szmyt (Uniwersytet Gdański). Zasadniczą tezą jego wystąpienia była myśl, że „Konstytucja musi być żywa i stale obecna w społeczeństwie". W tym celu Uniwersytet Gdański wydał pierwszą w historii Konstytucję RP w postaci audiobooka, poszerzając w ten sposób możliwość zapoznania się z jej treścią mającą wszak kluczowe znaczenie dla państwa polskiego.

Po wystąpieniach gości prelegenci rozpoczęli wygłaszanie swych referatów. Jako pierwsza swoje wystąpienie przedstawiła mgr Aleksandra Dębowska (Uniwersytet Jagielloński). W referacie pt. Tożsamość Konstytucji Rzeczypospolitej Polskiej z 1997 r. jako granica dopuszczalnej wykładni jej norm prelegentka skupiła się na zagadnieniu interpretacji norm ustawy zasadniczej, wskazując na jej specyfikę i odmienność od pozostałych źródeł prawa.

Drugim z mówców był mgr Władysław Jóźwicki, który wygłosił referat pt. Rzeczpospolita dobrem wspólnym wszystkich obywateli jako uzasadnienie wymogu wierności obywateli wobec niej w kontekście integracji europejskiej. W swym wystąpieniu odniósł się do dwóch zasadniczych zagadnień: konstytucyjnej klauzuli dobra wspólnego, a także - postrzeganego przez pryzmat owej klauzuli - obowiązku wierności obywateli wobec państwa polskiego oraz troski o dobro wspólne w kontekście integracji europejskiej.

Trzecią referentką była mgr Marcelina Stolarska (Uniwersytet Jagielloński). W referacie poświęconym dewaluacji Konstytucji z 1997 r. na tle najistotniejszych współczesnych wyzwań politycznych i społecznych prelegentka podjęła próbę udzielenia odpowiedzi na pytanie, czy istnieją prawne oraz pozaprawne instrumenty mogące wzmocnić autorytet Konstytucji RP z $1997 \mathrm{r}$.

Jako czwarta głos zabrała mgr Agata Niźnik-Mucha (Uniwersytet Jagielloński). Jej wystąpienie dotyczyło Zakazu naruszania istoty konstytucyjnych wolności i praw człowieka i obywatela jako ostatecznej bariery wobec ograniczenia tych wolności i praw przez ustawodawcę. Prelegentka wyraziła nadzieję, że wygłoszony przez nią referat stanowić będzie przyczynek do podjęcia pogłębionego dyskursu na temat znaczenia konsekwencji obowiązywania w polskim systemie prawa zakazu naruszania konstytucyjnych wolności i praw człowieka. 
Piątym prelegentem był mgr Jakub Jaraczewski (Uniwersytet Adama Mickiewicza w Poznaniu). W referacie pt. Bezpieczeństwo jako wartość chroniona w Konstytucji RP autor poddał analizie paradygmat bezpieczeństwa, wyjaśniając, jak pojemne i wieloznaczne jest to pojęcie. Dostrzegając naruszenia standardów ochrony praw człowieka i wolności jednostki w kontekście zapewnienia bezpieczeństwa, autor w sposób wstrzemięźliwy podszedł do postulatu zmiany Konstytucji RP. W pierwszej kolejności zaproponował poszukiwanie optymalnych rozwiązań poprzez modyfikację myślenia i postrzegania bezpieczeństwa.

Szósty referat, pt. Konstytucja RP wobec ekstremizmu politycznego - potencjalne problemy dla orzecznictwa Trybunału Konstytucyjnego oraz sądów, wygłosiła mgr Ada Paprocka z Uniwersytetu Warszawskiego. Autorka postawiła sobie za cel wskazanie, w jaki sposób Konstytucja z 1997 r. odpowiada na zagrożenia ze strony ruchów politycznych kwestionujących jej podstawowe założenia.

Kolejny referat, wygłoszony przez mgr. Michała Podsiadłę z Uniwersytetu Jagiellońskiego, dotyczył problematyki odporności polskiego ustroju na „sytuacje awaryjne”. Na początku swojego wystąpienia prelegent wyjaśnił, co rozumie pod pojęciem tytułowych „sytuacji awaryjnych”. Dokonując syntetycznej charakterystyki każdej z tych okoliczności, w dalszym toku wywodu starał się ukazać słabości polskiej regulacji konstytucyjnej w sytuacji wystąpienia którejś z tych okoliczności.

Ósmy referat, poruszający zagadnienie relacji pomiędzy klauzulą porządku publicznego a normami konstytucyjnymi wygłosił mgr Nikodem Rycko (Uniwersytet Warszawski). Po dokonaniu rekonstrukcji pojęcia „klauzuli porządku publicznego", prelegent przeprowadził analizę podstawowych zasad porządku prawnego Rzeczypospolitej Polskiej. Odwołując się do licznych orzeczeń sądowych, prelegent poddał krytyce fakt, iż przy stosowaniu tytułowej klauzuli w judykaturze dominuje ujęcie cywilistyczne, zaś stosunkowo niechętnie uwzględniana jest perspektywa konstytucyjna.

Kolejny referat, wygłoszony przez mgr. Jana Jodłowskiego (Uniwersytet Warszawski), dotyczył wpływu regulacji konstytucyjnych na zakres obowiązywania zasady prawdy materialnej w postępowaniu karnym. Prelegent wyjaśnił, jak doniosłe miejsce w systemie prawa karnego zajmuje zasada prawdy materialnej. W toku wywodu dopuścił jednak możliwość ograniczenia 
poziomu realizacji tej zasady z uwagi na bardziej skuteczne i pełniejsze zapewnienie efektywnego stosowania konstytucyjnej funkcji ochronnej.

Dziesiątym prelegentem był dr Bartłomiej Opaliński (Uczelnia Łazarskiego). W referacie zatytułowanym Funkcjonowanie władzy wykonawczej $z$ perspektywy 15 lat obowiązywania Konstytucji Rzeczypospolitej Polskiej $z 1997$ r. podjął próbę oceny konstytucyjnej regulacji usytuowania podmiotów władzy wykonawczej z perspektywy minionych piętnastu lat. Wskazując na pewne mankamenty w tym zakresie, prelegent zaproponował modyfikację polskiego systemu rządów w kierunku rozwiązań charakteryzujących „kanclerską” odmianę modelu parlamentarnego.

Pierwszą część wystąpień zamknął dr Maciej Pichlak (Uniwersytet Wrocławski), wygłaszając referat na temat potrzeby reinterpretacji konstytucyjnego modelu systemu źródeł prawa. Autor dostrzegł liczne niejasności wokół konstytucyjnego modelu systemu źródeł prawa i sformułował postulat ich zniwelowania. W tym celu, odwołując się do rozważań wielu wybitnych teoretyków prawa, zaproponował kilka możliwych płaszczyzn interpretacji tego modelu dających wpisać się we współczesne kanony myślenia prawniczego.

Wystąpienia jedenastu referentów zwieńczyła dyskusja, w której głos zabrali m.in. profesor Teresa Dębowska-Romanowska, profesor Kazimierz Działocha, profesor Sławomira Wronkowska-Jaśkiewicz i mgr Michał Ziółkowski. Z uwagi na ustaloną dyscyplinę czasową dyskusja przybrała jednak formę uwag spostrzegawczo-uzupełniających, niekiedy o lekko krytycznym zabarwieniu. Dyskutanci odnotowali swoje wątpliwości i sugestie w stosunku do niektórych wystąpień, zaś dalsze ożywione dyskusje toczyły się w kuluarach, zwłaszcza podczas godzinnej przerwy na lunch.

Rozpoczęcie drugiej części konferencji zostało uświetnione przez przybycie prezydenta Rzeczypospolitej Polskiej Bronisława Komorowskiego. W swoim wystąpieniu prezydent Komorowski podkreślił, że „oprócz rozwiązań zawartych w ustawie zasadniczej niesłychanie istotna jest praktyka polityczna, która może wykorzystać dobrą i złą konstytucję w dobry i zły sposób. W konsekwencji powstaje układ, w którym nawet przy bardzo dobrych rozwiązaniach, w obliczu konkretnych wyzwań i w rękach konkretnych osób ta sama konstytucja może dawać szanse na dobre reakcje, jak i może być narzędziem niewystarczającym”. Z perspektywy piętnastu lat obowiązywania Konstytucji prezydent stwierdził, że przyjęte w niej rozwią- 
zania dały Polsce stabilizację. Sprawdziły się bowiem w obliczu wielu trudnych sytuacji. W dalszej części wystąpienia Bronisław Komorowski podziękował zarówno za zaproszenie na Konferencję, jak też za znakomity pomysł spotkania, w którym głos zabierają ci, którzy się wychowali na nowej Konstytucji RP, a tamte dylematy sprzed lat dwudziestu są im znane jedyne z literatury i wykładów akademickich. Spotkanie - w którym ścierają się ze sobą doświadczenia wyniesione $\mathrm{z}$ minionych piętnastu lat stosowania konstytucji oraz oderwane od utartych schematów opinie młodych konstytucjonalistów - stanowi znakomitą okazję do podjęcia owocnej dyskusji.

W drugiej części konferencji jako pierwszy przedstawił swój referat dr Krzysztof J. Kaleta (Uniwersytet Warszawski). W swym wystąpieniu zatytułowanym Sądownictwo konstytucyjne a refleksyjny konstytucjonalizm w XXI wieku autor odniósł się zarówno do samej idei sądowej kontroli konstytucyjności, jak i do aktualnego kontekstu konstytucyjnego stawiającego tak przed teoretykami, jak i praktykami prawa zupełnie nowe wyzwania.

Następnie mgr Dobrochna Minich (Uniwersytet Wrocławski) wygłosiła referat pt. Trybunat Konstytucyjny - czy tylko negatywny ustawodawca? Refleksje nad statusem ustrojowym TK $w$ dobie kryzysu nowoczesności. Autorka wywiodła, że Trybunał Konstytucyjny ze względu na możliwość derogowania z systemu prawnego norm niekonstytucyjnych pozostaje tzw. ustawodawcą negatywnym. Powoduje to, iż będąc organem władzy sądowniczej wymyka się on z klasycznego rozdziału, jaki niesie za sobą zasada podziału władz.

Jako trzeci w drugiej części konferencji zabrał głos dr Michał Jackowski (Uniwersytet Warszawski). W swym referacie poruszył on problematykę wykonywania afirmatywnych wyroków Trybunału Konstytucyjnego przez Sąd Najwyższy i Naczelny Sąd Administracyjny, wskazując, że jest to jeden z elementów dialogu między sądami i trybunałami w Polsce.

Kolejna prelegentka - dr Marta Kłopocka-Jasińska (Wyższa Szkoła Prawa i Zarządzania im. Heleny Chodkowskiej, Wydział Zamiejscowy we Wrocławiu) - poświęciła swoje wystąpienie zagadnieniu wprowadzenia do polskiego systemu ustrojowego skargi konstytucyjnej na akt stosowania prawa w polskim porządku prawnym. Na podstawie przeprowadzonej analizy autorka ustaliła, że modyfikacja taka, jakkolwiek pożądana, w polskich warunkach ustrojowych wydaje się mało prawdopodobna. 
Piąty prelegent - dr Piotr Kociubiński (Uniwersytet Jagielloński) - poświęcił swoje wystąpienie zagadnieniu wykładni prawa, a dokładnie dyrektyw interpretacyjnych. Zasadniczym celem prelegenta było zbadanie konstytucyjnych źródeł hierarchii owych dyrektyw.

Następnie dr Grzegorz Maroń (Uniwersytet Rzeszowski) wygłosił referat poświęcony operacjonalizacji konstytucyjnych zasad prawa w orzecznictwie Trybunału Konstytucyjnego. W toku wywodu autor unaocznił dystans pomiędzy „konstytucją pisaną” i „konstytucją żyjącą”. W tym zakresie wskazał na doniosłą rolę orzecznictwa Trybunału Konstytucyjnego obudowującego tytułowe zasady bogatą treścią nadającą im praktyczną funkcjonalność.

Kolejny prelegent - mgr Marcin Rulka (Uniwersytet Łódzki) - przedstawił referat poświęcony treści konstytucyjnej zasady powszechności głosowania. W konkluzji swego wystąpienia stwierdził, że prawo do głosowania powinni posiadać wszyscy mający zdolność podejmowania samodzielne rozsądnej decyzji, rozumiejący jej konsekwencje. Jest to jedno z podstawowych kryteriów, które powinno spełniać każde współczesne państwo demokratyczne.

Referat na temat konstytucyjnej problematyki prawa do pracy u progu XXI wieku przedstawił mgr Andrzej Bigaj z Uniwersytetu Jagiellońskiego. Prelegent wyjaśnił, że polityka zatrudnienia powinna znaleźć szerszy oddźwięk w ustawie zasadniczej, zwłaszcza w zakresie zachodzących zmian $\mathrm{w}$ świecie pracy, otwierających nowe perspektywy, ale również zagrożenia dla realizacji praw społecznych.

Ostatnim referentem był mgr Krzysztof Świtała (Uniwersytet Kardynała Stefana Wyszyńskiego). W swoim wystąpieniu podjął problematykę prawa do uzyskiwania informacji o działalności organów władzy publicznej. W toku wywodu zwrócił uwagę na konieczność uwzględnienia rozwoju spoleczeństwa informacyjnego oraz gospodarki opartej na wiedzy i technologii informacyjno-komunikacyjnej w wykładni konstytucyjnego prawa do informacji o działalności organów władzy publicznej.

Zarówno niezwykle bogata i urozmaicona tematyka wystąpień prelegentów, jak również sama formuła konferencji, skierowanej wszak do najmłodszego pokolenia polskich przedstawicieli nauki prawa, wpływa na ogólną pozytywną, wysoką ocenę tego wydarzenia. Pomysłodawcy stworzyli znakomitą platformę wymiany poglądów dającą jednocześnie możliwości oce- 
ny rozwoju kadry naukowej przez grono starszych, bardziej doświadczonych przedstawicieli nauki prawa. Właściwym kierunkiem wydaje się wykształcenie praktyki obchodzenia każdego kolejnego jubileuszu polskiej ustawy zasadniczej w ten właśnie sposób. Kierując ten postulat do pomysłodawców konferencji, pozostaje nam z nadzieją oczekiwać na kolejną okrągłą rocznicę wejścia w życie Konstytucji Rzeczypospolitej Polskiej w październiku 2017 r.

Bartłomiej Opaliński (Uczelnia Łazarskiego w Warszawie) 